\title{
Association of adiponectin levels and insulin demand in critically ill patients
}

This article was published in the following Dove Press journal:

Diabetes, Metabolic Syndrome and Obesity:Targets and Therapy

25 January 2011

Number of times this article has been viewed

\author{
Andreas Hillenbrand' \\ Manfred Weiss ${ }^{3}$ \\ Uwe Knippschild' \\ Hans G Stromeyer' \\ Doris Henne-Bruns' \\ Markus Huber-Lang', \\ Anna MWolf', \\ 'Department of General, Visceral, \\ and Transplantation Surgery, \\ ${ }^{2}$ Department of Traumatology, \\ Hand and Reconstructive Surgery, \\ ${ }^{3}$ Department of Anesthesiology, \\ University Hospital of Ulm, \\ Ulm, Germany \\ †These authors contributed equally
}

Correspondence: Andreas Hillenbrand Department of General, Visceral, and Transplantation Surgery, University Hospital of Ulm, Steinhoevelstr 9, 89075 Ulm, Germany

$\mathrm{Tel}+4973$ I $5005361 \mathrm{I}$

Fax +4973। 50053503

Email andreas.hillenbrand@uniklinikulm.de
Purpose: Intensive care unit patients usually have a deregulated glucose homeostasis and present with hyperglycemia and hyperinsulinemia, suggesting overall insulin resistance. Adiponectin has significant anti-inflammatory and insulin-sensitizing effects and is diminished in morbidly obese and in critically ill patients. Reduced adiponectin could contribute to insulin resistance in these patients. We examined how far insulin demand in critically ill patients is correlated with patient adiponectin levels.

Patients and methods: Adiponectin, resistin, leptin, insulin demand, minimal and maximal blood sugar levels, epinephrine, and hydrocortisone demand were measured 1 day after diagnosis of severe sepsis or septic shock in 25 patients ( 8 female, 17 male; median age 65 years; range: 31 to 87 years).

Results: Insulin demand (range: $0-8 \mathrm{IU} / \mathrm{h}$; median $3.5 \mathrm{IU}$ ) was positively correlated with serum adiponectin levels (median: $10.1 \mu \mathrm{g} / \mathrm{mL}$; range: $2.9-47.6 \mu \mathrm{g} / \mathrm{mL} ; r=+0.56$, $P<0.01)$. There was no significant correlation between insulin demand and leptin serum levels (median: $18.1 \mathrm{ng} / \mathrm{mL}$; range: $0.3-80.7 \mathrm{ng} / \mathrm{mL} ; r=+0.29, P=0.08$ ) or resistin serum levels (median: $103.9 \mathrm{ng} / \mathrm{mL}$; range: $14.7-352.3 \mathrm{ng} / \mathrm{mL} ; r=+0.13, P=0.27$ ). Epinephrine demand (median: $0.08 \mu \mathrm{g} / \mathrm{kg} * \min$; range: $0.02-0.63 \mu \mathrm{g} / \mathrm{kg} * \min$ ) was negatively correlated with male adiponectin levels $(r=-0.58 ; P<0.01$; females: $r=-0.36 ; P=0.19)$ and positively correlated with resistin levels $\left(r=0.43 ; P=0.02\right.$ ). Patient body mass index (median $26 \mathrm{~kg} / \mathrm{m}^{2}$; range: 18-37) was positively correlated with serum leptin $(r=0.60 ; P<0.01)$ but was not correlated with insulin demand ( $r=0.19 ; P=0.19$ ), or adiponectin (females: $r=-0.37, P=0.18$; males: $r=-0.16, P=0.27)$, or resistin levels $(r=+0.17 ; P=0.21)$.

Conclusion: Adiponectin levels and insulin demand were positively correlated during sepsis. Adiponectin levels were negatively correlated with epinephrine demand in male patients and epinephrine demand was positively correlated with resistin levels, which might have increased insulin resistance. The relationship between adiponectin and insulin action in humans is more complex than often suggested.

Keywords: adipokines, sepsis, diabetes, resistin, leptin

\section{Introduction}

Patients who are critically ill often require prolonged intensive care and vital organ function support. These patients uniformly have a deregulated glucose homeostasis and present with hyperglycemia and hyperinsulinemia, suggesting overall insulin resistance. Maintaining normoglycemia with insulin therapy improves survival and reduces morbidity in surgical intensive care unit patients. ${ }^{1,2}$

Hyperglycemia in the presence of hyperinsulinemia also accompanies type 2 diabetes (T2DM), obesity, and the metabolic syndrome. These conditions are characterized by 
reduced inhibition of hepatic gluconeogenesis and impaired glucose uptake in insulin-sensitive tissues, such as skeletal muscle. $^{3}$

These metabolic processes are influenced by products of the adipose tissue, so-called adipokines, which play a crucial role in the pathogenesis of the metabolic syndrome. Adipokine levels are changed in the morbidly obese and these changed levels contribute to skeletal muscle and hepatic insulin resistance. ${ }^{4}$

Adiponectin, the most abundant adipokine exclusively derived from adipocytes with higher average levels in females compared with males, has excited intense interest because of robust correlation of its circulating levels with insulin resistance and risk of T2DM. Further, adiponectin has a significant anti-inflammatory and insulin-sensitizing effect., ${ }^{5,6}$ We have already demonstrated that adipokines like adiponectin or leptin are shifted in critically ill patients in the same direction as in morbidly obese and patients with T2DM. ${ }^{7}$ Adiponectin has an unusual inverse relationship with body mass index (BMI) and thus is diminished in the obese, but also in the critically ill. ${ }^{7,8}$ Since reduced adiponectin levels seems to contribute to insulin resistance in the obese, reduced adiponectin levels could also contribute to insulin resistance in critically ill patients.

Since higher adiponectin levels are associated with a lower risk of T2DM across diverse populations, ${ }^{9}$ we could speculate that higher adiponectin levels in critically ill patients cause a lower insulin demand.

Therefore, in this study, we determined adiponectin, resistin, and leptin levels in critically ill patients and analyzed the insulin demand in correlation to patients' adipokine levels.

\section{Materials and methods}

\section{Patient characteristics}

Twenty-five patients who fulfilled the clinical criteria for severe sepsis or septic shock were enrolled in this study. Eight patients were female and 17 male, with a median age of 65 years (range: $31-87$ years; female median age: 81 years, range: 42-87 years; male median age: 65 years, range: $31-83$ years). The criteria for severe sepsis and septic shock were in accordance with those defined by Bone. ${ }^{10}$ The Simplified Acute Physiology Score (SAPS II) and Sequential Organ Failure Assessment score (SOFA) without Glasgow Coma Scale were used to define the severity of disease and organ dysfunctions, respectively. ${ }^{11-13}$ Total adiponectin, resistin, and leptin were measured 1 day after diagnosis of severe sepsis or septic shock. Blood samples were collected at $5 \mathrm{AM}$ in the fasting state. Body weight and height for calculation of BMI of septic patients were self-reported (or estimated if no self-report was possible). Insulin was administered via perfusor syringe. International Units of insulin demand, minimal and maximal blood sugar levels, as well as epinephrine and hydrocortisone demand were determined within the first 24 hours after diagnosis of severe sepsis or septic shock.

For all measurements, $10 \mathrm{~mL}$ venous blood was collected in a chilled syringe with EDTA and immediately centrifuged at $1600 \times g$ for 15 minutes. Plasma was stored at $-80^{\circ} \mathrm{C}$ until analysis.

The study was performed with the permission of the independent local ethics committee of the University of Ulm (approval number 82/2002 and 73/2009). A written informed consent was obtained. If the patient was not capable of making decisions because of sedation or altered mental function, the informed consent was obtained after recovery as advised by the ethics committee. Exclusion criteria were: age $<18$ years, pregnancy, rapidly progressing underlying disease, HIV/AIDS, cardiogenic shock as the primary underlying disease, underlying hematologic disease, or cytotoxic therapy given within the previous 6 months.

\section{Adipokine measurement and reagents}

Multiplex analysis kits for leptin, resistin, and total adiponectin were obtained from Millipore, Hamburg, Germany. In brief, the appropriate adipokine standards and samples, diluted in plasma dilution buffer, were added to wells of a filtered plate. The samples were incubated with $50 \mu \mathrm{L}$ of the antibodycoupled microsphere set on a plate shaker in the dark at room temperature for 30 minutes. The samples were washed 3 times with $100 \mu \mathrm{L}$ wash puffer. Freshly diluted secondary detection antibody ( $25 \mu \mathrm{L} /$ well) was added to the wells and then incubated on a plate shaker in the dark at room temperature. Thereafter, samples were washed 3 times with $100 \mu \mathrm{L}$ wash buffer. Fifty microliters of strepavidin-PE $(16 \mu \mathrm{g} / \mathrm{mL}$ in assay buffer) was added to each well, and incubation continued on a plate shaker at room temperature for the first 10 minutes. Unbound analytes were filtered through the wells using the vacuum manifold. The bound beads were washed 3 times with $100 \mu \mathrm{L}$ wash buffer. After the last wash step, $125 \mu \mathrm{L}$ of assay buffer was added to each well and the plate was placed on a plate shaker set at $500 \mathrm{rpm}$ for 1 minute and then for 3 minutes at a reduced speed of $300 \mathrm{rpm}$. Finally, samples were analyzed on the Luminex system in accordance with the manufacturers' instructions. The system was sufficiently sensitive to analyze leptin values as low as $0.3 \mathrm{ng} / \mathrm{mL}$.

\section{Statistical analysis}

All values were expressed as median with range. The MannWhitney $U$ test was used to compare the data of septic patients. Analysis was performed with WinSTAT, Version 2009.1 (R.F. FitchSoftware). 
The Spearman rank-order correlation coefficient was calculated for correlation analysis. $R$ indicates the correlation coefficient. A value of $P<0.05$ was considered statistically significant. Correlation coefficient values between 0.3 and $0.7(-0.3$ and -0.7$)$ indicate a moderate linear relationship, and values between 0.7 and $1.0(-0.7$ and -1.0$)$ indicate a strong positive (negative) linear relationship. No adjustment for multiple testing has been made.

\section{Results}

The 25 septic patients (17 male and 8 female patients) had median SAPS II and SOFA scores of 37 (range: 21-58) and 9 (3-11), respectively. Median BMI was $26 \mathrm{~kg} / \mathrm{m}^{2}$ (range: 18-37). The underlying cause of sepsis with side diagnosis, gender, age, CRP and leukocyte levels, BMI, SAPS II (without Glasgow Coma Scale), and sepsis score according to the definition of Bone et $\mathrm{al}^{10}$ are shown in Table 1 .

Table I Gender, age, underlying reason of sepsis, side diagnosis, C-reactive protein levels, white blood count, self-reported (or estimated) body mass index, and Simplified Acute Physiology Score (SAPS II) without Glasgow Coma Scale of the 25 septic patients

\begin{tabular}{|c|c|c|c|c|c|c|c|c|}
\hline $\begin{array}{l}\text { Agel } \\
\text { gender }\end{array}$ & $\begin{array}{l}\text { Underlying } \\
\text { cause of sepsis }\end{array}$ & CRP (mg/L) & $\begin{array}{l}\text { White } \\
\text { bloodcount } \\
\text { (G/I) }\end{array}$ & BMI & $\begin{array}{l}\text { Side } \\
\text { diagnosis }\end{array}$ & $\begin{array}{l}\text { SAPS II } \\
\text { (without } \\
\text { GCS) }\end{array}$ & $\begin{array}{l}\text { SOFA } \\
\text { (without } \\
\text { GCS) }\end{array}$ & $\begin{array}{l}\text { Sepsis } \\
\text { score }^{a}\end{array}$ \\
\hline $62 / \mathrm{m}$ & $\begin{array}{l}\text { Acute necrotizing } \\
\text { pancreatitis }\end{array}$ & 85 & 12.7 & 27 & $\begin{array}{l}\text { Spastic hemi paresis, } \\
\text { nicotine and } A A / D\end{array}$ & 49 & 10 & 6 \\
\hline $83 / \mathrm{m}$ & $\begin{array}{l}\text { Perforated } \\
\text { gastric ulcer }\end{array}$ & 334 & 44.8 & 25 & NIDDM, aHT, TAA & 50 & 10 & 6 \\
\hline $67 / \mathrm{m}$ & $\begin{array}{l}\text { Postoperative } \\
\text { pancreatic fistula }\end{array}$ & 259 & 46.2 & 29 & NIDDM, aHT & 21 & 7 & 6 \\
\hline $42 / f$ & Necrotizing fasciitis & 323 & 17.5 & 28 & - & 58 & 9 & 7 \\
\hline $65 / \mathrm{m}$ & Necrotizing fasciitis & 283 & 24.3 & 25 & $\begin{array}{l}\text { DIDDM, aHT, } \\
\text { TAA, RI }\end{array}$ & 29 & 11 & 6 \\
\hline $66 / \mathrm{m}$ & Ischemic colitis & 289 & 18.2 & 26 & $\begin{array}{l}\text { DIDDM, aHT; } \\
\text { RI; PAOD }\end{array}$ & 34 & 9 & 6 \\
\hline $63 / \mathrm{m}$ & $\begin{array}{l}\text { Postoperative } \\
\text { bile peritonitis }\end{array}$ & 266 & 12.9 & 37 & $\begin{array}{l}\text { CHD, adipositas, } \\
\text { NIDDM, aHT }\end{array}$ & 31 & 9 & 6 \\
\hline $64 / \mathrm{m}$ & $\begin{array}{l}\text { Postoperative } \\
\text { paralytic ileus }\end{array}$ & 250 & 16.2 & 30 & - & 24 & 10 & 6 \\
\hline $86 / f$ & $\begin{array}{l}\text { Perforated } \\
\text { duodenal ulcers }\end{array}$ & 273 & 37.7 & 31 & aHT, dementia & 31 & 5 & 4 \\
\hline $50 / \mathrm{m}$ & $\begin{array}{l}\text { Esophageal } \\
\text { perforation }\end{array}$ & 138 & 15.5 & 26 & $\begin{array}{l}\text { Nicotine and AA/D; } \\
\text { liver cirrhosis }\end{array}$ & 40 & 11 & 6 \\
\hline $69 / \mathrm{m}$ & $\begin{array}{l}\text { Acute necrotizing } \\
\text { pancreatitis }\end{array}$ & 219 & 14.7 & 23 & Nicotine and AA/D & 24 & 8 & 6 \\
\hline $44 / m$ & Blunt chest trauma & 135 & 9.7 & 32 & - & 29 & 9 & 6 \\
\hline $67 / \mathrm{m}$ & $\begin{array}{l}\text { Colon anastomosis } \\
\text { insufficiency }\end{array}$ & 319 & 28,9 & 21 & Ulcerative colitis & 47 & 11 & 6 \\
\hline $65 / \mathrm{m}$ & Arterial bypass infection & 259 & 17.5 & 26 & $\begin{array}{l}\text { PAOD, AA/D, } \\
\text { COPD, HF }\end{array}$ & 37 & 9 & 6 \\
\hline $58 / f$ & $\begin{array}{l}\text { Gastric ulcers } \\
\text { peroration }\end{array}$ & 259 & 16.9 & 32 & $\begin{array}{l}\text { Nicotine and } \\
A A / D \text {, liver cirrhosis, } \\
\text { aHT, asthma }\end{array}$ & 53 & 10 & 6 \\
\hline $31 / \mathrm{m}$ & Pleural empyema & 330 & 17.5 & 28 & - & 29 & 7 & 6 \\
\hline $64 / \mathrm{m}$ & $\begin{array}{l}\text { Colon anastomosis } \\
\text { insufficiency }\end{array}$ & 102 & 21.6 & 23 & - & 46 & 11 & 6 \\
\hline $66 / \mathrm{m}$ & Gastric ulcers peroration & 200 & 26.7 & 24 & CHD, PAOD, COPD & 48 & 9 & 4 \\
\hline $87 / f$ & Gastric ulcers peroration & 213 & 16.3 & 22 & $\mathrm{aHT}, \mathrm{TAA}, \mathrm{HF}$ & 41 & 5 & 4 \\
\hline $80 / f$ & Anaphylactic shock & 134 & 14.3 & 25 & NIDDM, aHT & 54 & 5 & 5 \\
\hline $81 / f$ & $\begin{array}{l}\text { Postoperative } \\
\text { abdominal infection }\end{array}$ & 274 & 37.3 & 24 & COPD & 46 & 6 & 6 \\
\hline $87 / f$ & Aspiration pneumonia & 235 & 18.9 & 28 & COPD & 54 & 9 & 6 \\
\hline $50 / f$ & Retroperitoneal abscess & 178 & 18.8 & 26 & $\mathrm{RI}, \mathrm{aHT}$ & 31 & 3 & 4 \\
\hline $44 / m$ & Necrotizing fasciitis & 130 & 15.1 & 31 & Nicotine and AA/D, RI & 28 & 6 & 6 \\
\hline $80 / \mathrm{m}$ & Empyema & 225 & 17.6 & 18 & $\begin{array}{l}\text { COPD, nicotine } \\
\text { abuse, RI }\end{array}$ & 31 & 9 & 4 \\
\hline
\end{tabular}

Note: ${ }^{\text {a }}$ epsis score $\left(\right.$ Bone et al ${ }^{10}$ ): 4 , sepsis, 5, severe sepsis, 6, septic shock.

Abbreviations: AA/D, alcohol abuse/dependence; aHT, arterial hypertension; CHD, coronary heart disease; COPD, chronic obstructive pulmonary disease; CRP, C-reactive protein; GCS, Glasgow Coma Scale; G/I, Giga/liter; HF, heart failure; NIDDM, noninsulin dependent diabetes mellitus; PAOD, peripheral artery occlusive disease; RI, renal insufficiency; TAA, tachyarrhythmia absoluta. 
Median resistin level was $103.9 \mathrm{ng} / \mathrm{mL}$ (range: 14.7-352.3 ng/mL), median leptin level was $18.1 \mathrm{ng} / \mathrm{mL}$ (range: $0.3-80.7 \mathrm{ng} / \mathrm{mL}$ ). Median gender specific adiponectin serum levels were $14.1 \mu \mathrm{g} / \mathrm{mL}$ for female (range: $5.3-$ $47.6 \mu \mathrm{g} / \mathrm{mL}$ ) and $9.6 \mu \mathrm{g} / \mathrm{mL}$ (range: $2.9-32.6 \mu \mathrm{g} / \mathrm{mL}$ ) for male patients. The 2 extreme values of adiponectin $(47.6 \mu \mathrm{g} / \mathrm{mL}$ in female patients and $32.6 \mu \mathrm{g} / \mathrm{mL}$ in male patients) represent the 2 patients with the lowest BMI $\left(22 \mathrm{~kg} / \mathrm{m}^{2}\right.$ and $\left.18 \mathrm{~kg} / \mathrm{m}^{2}\right)$ and the lowest leptin levels $(0.9 \mathrm{ng} / \mathrm{mL}$ and $0.3 \mathrm{ng} / \mathrm{mL}$, respectively), although BMI showed no significant negative correlation with adiponectin levels (females: $r=-0.37$, $P=0.18$; males: $r=-0.16, P=0.27$ ).

Minimal blood sugar levels ranged between $63 \mathrm{mg} / \mathrm{dL}$ and $119 \mathrm{mg} / \mathrm{dL}$ (median $91 \mathrm{mg} / \mathrm{dL}$ ), and maximal levels ranged from 122 to $398 \mathrm{mg} / \mathrm{dL}$ (median $193 \mathrm{mg} / \mathrm{dL}$ ).

Insulin demand ranged from 0 to $8 \mathrm{IU} / \mathrm{h}$ (median $3.5 \mathrm{IU} / \mathrm{h}$ ). When sepsis was diagnosed, 23 out of 25 patients required insulin; 15 out of 25 patients required hydrocortisone (preponderant $8 \mathrm{mg} / \mathrm{h}$; range: $0-10 \mathrm{mg} / \mathrm{h}$ ), and all septic patients required epinephrine (median: $0.08 \mu \mathrm{g} / \mathrm{kg} * \mathrm{~min}$; range: $\left.0.02-0.63 \mu \mathrm{g} / \mathrm{kg}^{*} \mathrm{~min}\right)$. There was no gender difference in resistin and leptin levels, insulin, hydrocortison, and adrenalin demand or in minimal and maximal blood sugar levels.

There was a positive correlation of insulin demand after diagnosis of sepsis and serum adiponectin levels (all patients: $r=+0.57, P<0.01$; female patients: $r=+0.61, P=0.05$; Figure 1A; male patients: $r=+0.53, P=0.01$; Figure 1B). Multivariate regression analyses with adjustment for age and BMI showed a largely unchanged significant positive correlation between insulin demand after diagnosis of sepsis and serum adiponectin levels $(P=0.02 ; 95 \%$ confidence interval: $0.02-0.2)$. There was no significant correlation between insulin demand and leptin $(r=+0.29, P=0.08)$ or resistin ( $r=+0.13, P=0.27$; Table 2$)$ serum levels.

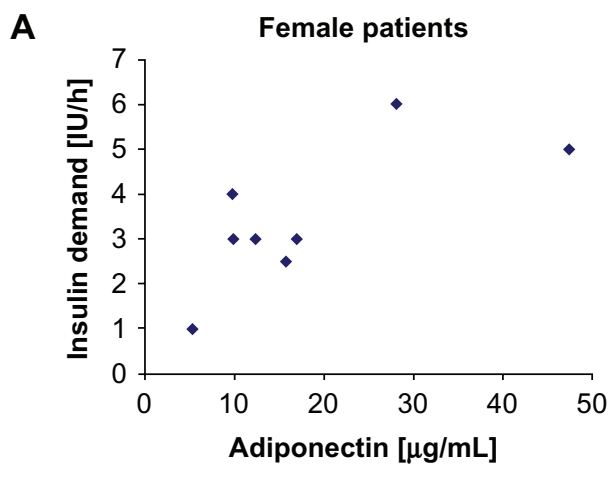

Epinephrine demand was negatively correlated with male adiponectin levels $(r=-0.58 ; P<0.01$; female: $r=-0.36 ; P=0.19)$ and positively correlated with resistin levels $(r=0.43 ; P=0.02$; Table 2$)$. There was no correlation between epinephrine and insulin $(r=0.12 ; P=0.28)$ and leptin $(r=0.24 ; P=0.13)$.

Patients who received hydrocortisone $(\mathrm{n}=15)$ had mean insulin demand of $5 \mathrm{IU} / \mathrm{h}$ (range: $1.0-8.0 \mathrm{IU} / \mathrm{h}$ ), while patients who received no hydrocortisone $(\mathrm{n}=10)$ had mean insulin demand of $2 \mathrm{IU} / \mathrm{h}$ (range: $0.0-5.0 \mathrm{IU} / \mathrm{h} ; P=0.01$ ). The mean adiponectin levels were not significantly different regardless of whether patients received hydrocortisone $(10.3 \mu \mathrm{g} / \mathrm{mL}$ vs $10.0 \mu \mathrm{g} / \mathrm{mL} ; P=0.20)$. Furthermore, groups showed no difference in SAPS II and SOFA scores $(P=0.46 ; P=0.41)$.

There was no correlation between patient age and SAPS II and SOFA scores, insulin, hydrocortisone, and adrenalin demand, or any analyzed serum parameter (adiponectin, resistin, and leptin). Five patients had pre-existing T2DM. These 5 patients showed no difference in any analyzed parameter.

Patient BMI was positively correlated with serum leptin $(r=0.60 ; P<0.01)$ but not with insulin demand $(r=0.19$; $P=0.19$ ), or adiponectin (female: $r=-0.37, P=0.18$; male: $r=-0.16, P=0.27)$, or resistin $(r=+0.17 ; P=0.21)$ levels.

\section{Discussion}

Adipose tissue is essentially involved in complex body hormone and cytokine production and cannot stand by passively in septic conditions. In septic conditions, adipokines are shifted in the same direction as in obese subjects and patients with T2DM, which implies lowered serum levels of adiponectin. Recent research indicated that adiponectin has anti-inflammatory, anti-atherogenic, and

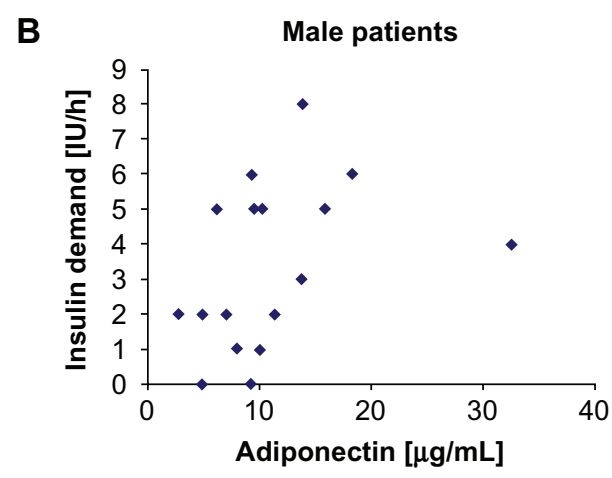

Figure I A,B) Insulin demand after diagnosis of sepsis and serum adiponectin levels of female (Figure IA) and male (Figure IB) patients. The 2 extreme values of adiponectin $\left(47.6 \mu \mathrm{g} / \mathrm{mL}\right.$ in female patients and $32.6 \mu \mathrm{g} / \mathrm{mL}$ in male patients) represent the 2 patients with the lowest body mass index $\left(22 \mathrm{~kg} / \mathrm{m}^{2}\right.$ and $\left.18 \mathrm{~kg} / \mathrm{m}^{2}\right)$ and the lowest leptin levels $(0.9 \mathrm{ng} / \mathrm{mL}$ and $0.3 \mathrm{ng} / \mathrm{mL}$, respectively), although body mass index showed no significant negative correlation with adiponectin levels (females: $r=-0.37, P=0.18$; males: $r=-0.16, P=0.27)$. 
Table 2 Correlation of adipokines with insulin and epinephrine application in patients with sepsis (correlation coefficient $r$ and $P$ values)

\begin{tabular}{|c|c|c|c|c|}
\hline Correlation of & With & All patients & Female & Male \\
\hline Insulin & Adiponectin & $0.57 ;<0.01$ & $0.6 I ; 0.05$ & $0.53 ; 0.01$ \\
\hline Insulin & Leptin & $0.29 ; 0.08$ & $-0.24 ; 0.28$ & $0.53 ; 0.014$ \\
\hline Insulin & Resistin & $0.13 ; 0.27$ & $-0.02 ; 0.48$ & $0.24 ; 0.18$ \\
\hline Insulin & Hydrocortisone & $0.52 ; P<0.01$ & $0.36 ; 0.19$ & $0.59 ;<0.01$ \\
\hline Insulin & BMI & $0.19 ; 0.19$ & $0.12 ; 0.39$ & $0.22 ; 0.20$ \\
\hline Epinephrine & Adiponectin & $-0.54 ;<0.01$ & $-0.36 ; 0.19$ & $-0.58 ;<0.0$ I \\
\hline Epinephrine & Resistin & $0.43 ; 0.02$ & $0.79 ; 0.01$ & $0.23 ; 0.19$ \\
\hline BMI & Adiponectin & $-0.17 ; 0.21$ & $-0.37 ; 0.18$ & $-0.16 ; 0.27$ \\
\hline BMI & Leptin & $0.60 ;<0.01$ & $0.61 ; 0.05$ & $0.59 ;<0.01$ \\
\hline BMI & Resistin & $0.17 ; 0.21$ & $0.68 ; 0.03$ & $-0.02 ; 0.47$ \\
\hline
\end{tabular}

Note: Bold values indicate significant positive or negative correlations.

Abbreviation: BMI, body mass index.

antidiabetic properties. The ability of adiponectin to reduce insulin resistance in conjunction with its anti-inflammatory properties makes adiponectin a potentially promising therapeutic target, and agents that enhance adiponectin secretion or action have potential to treat metabolic disease. ${ }^{14}$

Because lowered adiponectin levels are associated with insulin resistance, ${ }^{15}$ we hypothesized that patients with lower adiponectin serum levels in septic conditions have a higher insulin demand. Surprisingly, however, insulin demand showed a positive correlation to serum adiponectin levels - especially since direct testing of the effect of insulin infusion in healthy subjects has shown that insulin suppresses adiponectin levels in vivo. ${ }^{16}$

A possible rationale for this unexpected correlation may be that adiponectin levels are more influenced by the septic condition than adiponectin levels influence insulin demand, particularly since adiponectin levels correlate negatively with SAPS II and SOFA scores. ${ }^{7}$

Furthermore, insulin secretion is influenced by multiple hormones. Besides adipose tissue-derived hormones, a variety of other hormones has been discovered in recent years. Possible candidate hormones that can enhance insulin secretion are the so-called incretins, ie, gut peptide hormones, which are secreted in response to a meal. ${ }^{17}$ Referring to insulin demand, these hormones could be more involved compared with adiponectin through their insulin-secreting effect, although incretins seem to be responsible for higher insulin release after an oral glucose load compared with an intravenous glucose load. ${ }^{18}$

In addition to incretins, there are also a number of other hormones like ghrelin or peptide YY. Ghrelin has been shown to inhibit insulin secretion in humans ${ }^{19}$ and ghrelin levels seem to be elevated in fasting conditions. ${ }^{20}$ Similarly, recent studies have suggested more direct effects of peptide YY on insulin sensitivity, ${ }^{21}$ but the role of peptide YY independent of food intake still needs to be confirmed. Since all septic patients enrolled in this study were fed exclusively parenterally, the insulin-secreting stimulus of incretins and other gut hormones was expected to be reduced. ${ }^{22}$ No data exist to show the extent to which septic conditions influence gut hormone release.

It is difficult to say how patient insulin demand in this study was influenced by hydrocortisone supply. Insulin resistance in critically ill patients and patients with systemic inflammatory response syndrome was classically attributed to increased serum levels of cortisol, which promotes gluconeogenesis and inhibits peripheral glucose disposal in a stress-dependent manner. ${ }^{23}$ Ten out of 25 patients received low-dose hydrocortisone $(8-10 \mathrm{mg} / \mathrm{h})$. Notably, mean adiponectin levels of patients receiving hydrocortisone were almost identical with those of patients receiving no hydrocortisone $(10.3 \mu \mathrm{g} / \mathrm{mL}$ vs $10.0 \mu \mathrm{g} / \mathrm{mL})$. Also, both groups had similar SAPS II and SOFA scores.

Resistin, a protein with proinflammatory properties secreted by adipocytes and monocytes, has recently been reported to participate in the inflammatory response. ${ }^{24}$ Secretion of resistin is stimulated by insulin and inflammatory processes, glucocorticoids, and lipopolysaccharides, whereas tumor necrosis factor $\alpha$ and $\beta$-adrenergic stimulation act as inhibitors. Resistin levels are generally more elevated in obese patients and those with T2DM. ${ }^{25}$ Elevated resistin levels also seem to play a crucial role in insulin resistance. ${ }^{26}$ Resistin levels were positively correlated with SAPS II score $(r=0.39, P=0.03)$ and epinephrine demand ( $r=0.43 ; P=0.02$ ) supporting participation of resistin in the inflammatory response process. On the other hand, gender specific adiponectin, a protein with anti-inflammatory or 
insulin-sensitizing properties ${ }^{27}$ showed a negative correlation with epinephrine demand - especially in male patients ( $r=-0.58 ; P<0.01)$.

This study had several limitations: it had a small sample size, and male patients were significantly younger than female patients. However, patient age failed to show any significant correlation with the various analyzed values. Adipokines were analyzed only once, rather than at several time points through the septic course. Hydrocortisone substitution was performed only in patients with septic shock, with expected prolonged use of epinephrine infusion to maintain mean arterial pressure. Another crucial point was the self-reported/ estimated bodyweight and the heterogeneity of the septic group including patients with different causes of sepsis. This case mix reflects the typical clinical situation in intensive care units, however.

This study intended to explore the relationship between adipokine levels and insulin demand in critically ill patients. It represents an explorative study that hypothesized a possible trend, namely, that the relationship between adiponectin and insulin action in humans is more complex than often suggested. ${ }^{28}$

\section{Conclusion}

An unexpected positive correlation between adiponectin levels and insulin demand was found during sepsis. Adiponectin levels correlated negatively with epinephrine demand in male patients. On the other hand, epinephrine demand showed a positive correlation with resistin levels, which might have increased insulin resistance. Taken together, the sum effect of all the variables involved might have outweighed the expected negative correlation between insulin demand and adiponectin.

\section{Acknowledgments}

We thank M Templin, NMI, Tübingen, Germany for analyzing the cytokines.

\section{Disclosure}

The authors declare that they have no conflicting interests.

\section{References}

1. Langouche L, van den Berghe G. Glucose metabolism and insulin therapy. Crit Care Clin. 2006;22(1):119-129.

2. Van den Berghe G, Wilmer A, Hermans G, et al. Intensive insulin therapy in the medical ICU. $N$ Engl J Med. 2006;354(5):449-461.

3. Fritsche L, Weigert C, Häring HU, Lehmann R. How insulin receptor substrate proteins regulate the metabolic capacity of the liver implications for health and disease. Curr Med Chem. 2008;15(13): $1316-1329$.
4. Rabe K, Lehrke M, Parhofer KG, Broedl UC. Adipokines and insulin resistance. Mol Med. 2008;14(11-12):741-751.

5. Ouchi N, Kihara S, Funahashi T, et al. Reciprocal association of C-reactive protein with adiponectin in blood stream and adipose tissue. Circulation. 2003;107(5):671-674.

6. Dyck DJ. Adipokines as regulators of muscle metabolism and insulin sensitivity. Appl Physiol Nutr Metab. 2009;34(3):396-402.

7. Hillenbrand A, Knippschild U, Weiss M, et al. Sepsis induced changes of adipokines and cytokines - septic patients compared to morbidly obese patients. BMC Surg. 2010;10(1):26.

8. Arita Y, Kihara S, Ouchi N, et al. Paradoxical decrease of an adiposespecific protein, adiponectin, in obesity. Biochem Biophys Res Commun. 1999;257(1):79-83.

9. Li S, Shin HJ, Ding EL, van Dam RM. Adiponectin levels and risk of type 2 diabetes: a systematic review and meta-analysis. JAMA. 2009; 302(2):179-188.

10. Bone RC, Balk RA, Cerra FB, et al. Definitions for sepsis and organ failure and guidelines for the use of innovative therapies in sepsis: the ACCP/SCCM Consensus Conference Committee: American College of Chest Physicians/Society of Critical Care Medicine. Chest. 1992; 101(6):1644-1655.

11. Le Gall JR, Lemeshow S, Saulnier F. A New Simplified Acute Physiology Score (SAPS II) based on a European/North American multicenter study. JAMA. 1993;270:2957-2963.

12. Teasdale G, Jennett B. Assessment of coma and impaired consciousness. A practical scale. Lancet. 1974;2:81-84.

13. Janssens U, Dujardin R, Graf J, et al. Value of SOFA (Sequential Organ Failure Assessment) score and total maximum SOFA score in 812 patients with acute cardiovascular disorders. Critical Care. 2001; 5(suppl 1):P225x.

14. Matsuzawa Y. Adiponectin: identification, physiology and clinical relevance in metabolic and vascular disease. Atheroscler Suppl. 2005; 6(2):7-14.

15. Yu YH, Ginsberg HN. Adipocyte signaling and lipid homeostasis: sequelae of insulin-resistant adipose tissue. Circ Res. 2005;96(10): 1042-1052.

16. Basu R, Pajvani UB, Rizza RA, Scherer PE. Selective downregulation of the high molecular weight form of adiponectin in hyperinsulinemia and in type 2 diabetes: differential regulation from nondiabetic subjects. Diabetes. 2007;56(8):2174-2177.

17. Laferrère $B$, Heshka $S$, Wang $K$, et al. Incretin levels and effect are markedly enhanced 1 month after Roux-en-Y gastric bypass surgery in obese patients with type 2 diabetes. Diabetes Care. 2007;30(7): 1709-1716.

18. Verspohl EJ. Novel therapeutics for type 2 diabetes: incretin hormone mimetics (glucagon-like peptide-1 receptor agonists) and dipeptidyl peptidase-4 inhibitors. Pharmacol Ther. 2009;124(1):113-138.

19. Broglio F, Arvat E, Benso A, et al. Ghrelin, a natural GH secretagogue produced by the stomach, induces hyperglycemia and reduces insulin secretion in humans. J Clin Endocrinol Metab. 2001;86(10): 5083-5086.

20. Nakahara K, Okame R, Katayama T, Miyazato M, Kangawa K, Murakami N. Nutritional and environmental factors affecting plasma ghrelin and leptin levels in rats. J Endocrinol. 2010;207(1): 95-103.

21. Van den Hoek AM, Heijboer AC, Voshol PJ, et al. Chronic PYY3-36 treatment promotes fat oxidation and ameliorates insulin resistance in C57BL6 mice. Am J Physiol Endocrinol Metab. 2007;292(1): E238-E245.

22. Billyard T, McTernan P, Kumar S. Potential therapies based on antidiabetic peptides. Best Pract Res Clin Endocrinol Metab. 2007;21(4): 641-655.

23. Lehrke M, Broedl UC, Biller-Friedmann IM, et al. Serum concentrations of cortisol, interleukin 6, leptin and adiponectin predict stress induced insulin resistance in acute inflammatory reactions. Crit Care. 2008; 12(6):R157. 
24. Nagaev I, Bokarewa M, Tarkowski A, Smith U. Human resistin is a systemic immune-derived proinflammatory cytokine targeting both leukocytes and adipocytes. PLOS ONE 1. 2006:e31.

25. Pang SS, Le YY. Role of resistin in inflammation and inflammationrelated diseases. Cell Mol Immunol. 2006;3(1):29-34.

26. Steppan CM, Lazar MA. Resistin and obesity-associated insulin resistance. Trends Endocrinol Metab. 2002;13(1):18-23.
27. Maury E, Brichard SM. Adipokine dysregulation, adipose tissue inflammation and metabolic syndrome. Mol Cell Endocrinol. 2010; 314(1):1-16.

28. Cook JR, Semple RK. Hypoadiponectinemia - cause or consequence of human "insulin resistance"? J Clin Endocrinol Metab. 2010;95(4): $1544-1554$.

\section{Publish your work in this journal}

Diabetes, Metabolic Syndrome and Obesity: Targets and Therapy is an international, peer-reviewed open-access journal committed to the rapid publication of the latest laboratory and clinical findings in the fields of diabetes, metabolic syndrome and obesity research. Original research, review, case reports, hypothesis formation, expert opinion and commentaries are all considered for publication. The manuscript management system is completely online and includes a very quick and fair peer-review system, which is all easy to use. Visit http://www.dovepress.com/testimonials.php to read real quotes from published authors.

Submit your manuscript here: http://www.dovepress.com/diabetes-metabolic-syndrome-and-obesity-targets-and-therapy-journal 